\title{
10. Twisting the Pedagogy in Military Education - Experiences Drawn from a Problem-based Teaching Approach at the Norwegian Defence University College
}

Rino Bandlitz Johansen, Anders McD Sookermany \& Geir Isaksen

I have noticed over the past several years that there is an increasing dissonance between what we are doing with regards to training and education, and what we need to be doing based on the evolving operating environment. Specifically, many of our schools and training venues are based in the "lecture, memorize facts, regurgitate facts on command" model of industrial age training and education. ... What we need is an information age approach that is focused on active, student-centered learning using a problem-posing methodology where our students/ trainees are challenged with problems that they tackle as groups in order to learn by doing, and also from each other. We must enable them to think critically, recognize when change is needed and inculcate a bias for action without waiting to be told what to do. - General David H Berger, Commander US Marine Corps, (United States Marine Corps (2019) 
Above, General Berger of the U.S. Marine Corps raises fundamental questions about the inadequacies of military education. Believing military pedagogy to be unsatisfactory in its current state, he both calls for reforms and offers solutions founded on the implementation of more appropriate teaching methods, to be supported by developments in educational technologies affording broader and more rapid information sharing, networking, and access to an increasing number of decentralised knowledge sites. It is worth noting, however, that learning technologies are not always well grounded in pedagogical principles (Scoppio \& Covell, 2016) and the development and application of satisfactory pedagogy is on the agenda of professional military education (PME) in both non-Western and NATO nations (Duraid \& Annen, 2019; Hamilton, 2019; Walker, 2006). These factors mentioned above push the armed forces towards a more efficient type of education, harmonised with the civilian system. Norwegian military educators have addressed the ways in which appropriate learning philosophies might be developed (Isaksen, 2019; Sookermany, 2017; Torgersen \& Herner, 2015). One notable example of a shift in educational practice is the newly implemented educational strategy for the Norwegian Defence University College (Norwegian Defence University College, 2019a), presenting changes in both learning outcomes and existing pedagogy. Among its solutions, the strategy suggests that problem-based learning (PBL), or more student-active teaching methods, could be a mean to meet some of those challenges.

PBL can be described as "an instructional (and curricular) learner-centred approach that empowers learners to integrate theory and practice, applying knowledge and skills to develop a viable solution to a defined problem" (Savery, 2006). The underlying philosophy is that learning ought to be considered a constructive, self-directed, collaborative and contextual activity (Dolmans, De Grave, Wolfhagen \& Van der Vleuten, 2005). This accords both with the fundamental principles of military education suggested by Goode (2019) and with the collective nature of the military profession itself (Caforio, 2006). PBL serves as a vehicle for acquiring better problem-solving skills while laying the groundwork for new information to be acquired through self-directed learning (Bishop \& Verleger, 2013; Car et al., 2019). PBL also fits the collective nature of the military profession when it comes to operating in groups, depending on mutual trust and high levels of collaboration in the creation and solution of operational issues, whilst constantly in the process of "learning to learn."

If PBL might be considered a method advantageous for military education, however, a review of the literature reveals conspicuously few empirical studies for this specific application. With its origin and impact in health care education, the few extant studies of PBL in a military context largely focus on medical perspec- 
tives, and only sporadically on the digital and Virtual Reality domain. The degree to which PBL could be beneficial in other core domains of military education command, leadership and operations, for example - appears to be less explored, particularly through empirical study. The purpose of this study, then, is to provide more empirical material on the subject and a more systematic view on the use of PBL in military education. By using an explorative design, we investigate how the principles of PBL affect learning outcomes among executive Master's students following the Military Leadership (ML) course at the Norwegian Defence University College (NDUC).

The study is framed as a pilot. This is a methodically conscious choice allowing us to take an explorative approach rather than merely serving to confirm existing knowledge. Going into the pilot project, we envisioned several potential contributions. First, to widen the theoretical and empirical field of military education and learning, including the forming of new educational hypotheses pertaining to a military environment; second, if PBL were found to bring positive effects such as enhanced learning, our findings could pave the way for introducing more appropriate and differentiated pedagogical methods (beyond the field of health care) into military education; third, to inspire further exploration of and thoughts about fruitful ways to pedagogically improve military education in the years to come.

The study's findings may also be relevant beyond a purely military setting - to practical MBAs (Mintzberg 2004) and other executive studies, for example. Despite the fact that the study is performed in a Norwegian context, the contributions should apply to professional military education in general. Based on the above, the following two basic questions, organised into two separate sections, were pursued: did we succeed in providing a problem-based, student-centric teaching method? Did the change in pedagogy enhance learning outcomes for the students?

\section{Theoretical and Empirical Framework}

\section{Military Education: Leadership, Planning and Conduct Of Operations}

Professional education is a prerequisite for a successful military organisation (Gleiman \& Zacharakis, 2016). Since both the planning and execution of military operations are characterised by uncertainty, military students must be prepared for the unpredictable (Torgersen \& Herner, 2015; Sookermany, 2017). The leadership philosophy of contemporary armed forces relies on the principle of mission 
command, according to which all missions and tasks must be viewed in the light of the commanders' intent (Behn-Shalom \& Shamir, 2011; Norwegian Defence University College, 2019b; Jacobsen, 1993). For mission command to be effective, its underlying principles must be variously recognised, learned and trained in the course both of education and in the performance of operations. These principles revolve around the functioning of teams whose cohesion is established through a mutual trust affording both a shared, clear understanding of commander's intent and the exercise of disciplined initiative, following mission orders, with the acceptance of prudent risk (McBride \& Snell, 2017). In the pursuit of these principles, the pedagogy forming both the basis of mission command and the planning and conduct of military operations may be considered, essentially, a question of teaching students to think in a critical and constructive way given the situation and the commander's intent.

In the recent military anthology "Pedagogy for the Unforeseen," Torgersen and Herner (2015) argue that the learning objective is not the solution of any designated problem; it is, rather, both how the students reason before they arrive at a decision and their ability to elaborate on, and defend, their choices. This understanding is clearly reflected in the description of the overall learning outcome for the Master's of Military Study Programme (MoMS) at NDUG, where the development of the students' analytical and problem-solving skills is emphasised (Norwegian Defence University College, 2019d). In this respect, the proper choice of pedagogic design is critical. Ideally, it should support mutual goals. As such, the teaching method of PBL, through its emphasis on problem elaboration and relevant processes of analysis, may be expected to add value to military education, not only to the deeper learning of any particular subject, but to the enhancement of mission command and the planning and conduct of operations - especially when it comes to the analysis of complex operational problems and the development of alternative causes of action (Shamir, 2011).

\section{Problem-Based Learning}

In the literature, problem-based learning as a concept seems increasingly popular and does not necessarily refer to a specific or formalised educational method. In their Handbook of Problem Based Learning, Wijnia, Lovens and Rikers (2019) argue that it is not possible to identify any "ideal" model of PBL. Nevertheless, Savery (2006) has attempted to define PBL as "an instructional (and curricular) learner-centred approach that empowers learners to integrate theory and practice, applying knowledge and skills to develop a viable solution to a defined problem." In contrast to PBL, Barrows (2002) defined traditional learning approaches 
to be "large-class, instructor-driven, lecture-based deliveries within a curriculum, which compartmentalized the content."

Acknowledging that problem-based learning is not strictly defined, theorists and researchers still agree on a set of principles and characteristics: the method is understood to be student-centred, for example, and learning occurs in small groups; the role of the teacher is to facilitate learning activities rather than to simply impart information; the approach stimulates learning by obliging students to organise themselves; it promotes the attainment of improved problem-solving skills, and lays the groundwork for new information to be obtained through self-directed learning (Car et al., 2019; Bishop \& Verleger, 2013). PBL appeals to many educators because it offers a framework supporting active and group learning, considered an ideal in military education. As PBL offers opportunities for problem-solving in a collaborative setting and creates mental models for learning and forming self-directed learning habits through practice and reflection (Palinscar, 1998), we see clear parallels between PBL and the structure of military planning doctrines. Barrows (1996) highlighted five expected positive outcomes for students subjected to PBL:

1. The development of flexible knowledge.

2. The development of effective problem-solving skills.

3. Augmented self-directed learning skills.

4. Augmented collaboration skills.

5. The encouragement of intrinsic motivation for the learning process.

\section{Is Problem-Based Learning Working?}

The teaching method of PBL has been used in many disciplines for nearly four decades (Savery, 2006). Research comparing the effectiveness of PBL to more conventional teaching approaches is somewhat mixed and inconclusive (Wong \& Lam, 2007). In a meta-analysis of 43 studies, Dochy, Segers, Van den Bossche \& Gijbels (2003) concluded that PBL consistently helped students in skills-related outcomes. Savery (2006) found that students almost universally reported high levels of satisfaction with PBL courses and repeatedly stated that they generally preferred this method over traditional approaches. Studies on the effectiveness of PBL have largely focused on the field of medicine (Yew \& Goh, 2016), especially nursing and health care. In their meta-analysis, Shin and Kim (2013) revealed that PBL had positive effects on student satisfaction in training, clinical education, and skills development. When reviewing literature on the method's effect on students' critical thinking, Oja (2011) found a positive relationship between the 
implementation of PBL and improvements in critical reasoning. In a recent meta-analysis exploring the effects of PBL in pharmacology education, it was found that PBL played a role in the attainment of higher theoretical scores assessed through examinations (Liu, Du, Zhang \& Zhou, 2009). Student feedback also showed that PBL was superior to conventional teaching methods in improving outcomes of self-study, learning interest, team spirit, problem solving, analytical skills, scope of knowledge, communication and expression. In their meta-analysis, Strobel and van Barneveld (2009) pointed to PBL being significantly more effective than traditional instruction for training competent and skilled practitioners and for encouraging the long-term retention of knowledge and skills acquired during the learning experience or training session.

A review of the literature reveals a surprising scarcity of studies, particularly empirical studies, addressing the military context. In their study mapping trends in pedagogical approaches to military education, Scoppio and Covell (2016) suggest that institutions of advanced military education receive scrutiny and pressure to adapt to pedagogical trends in order to become "learning organisations" that create meaningful learning situations. From a Norwegian perspective, a technical report from the Army War Academy (Skaug 2008) explored teaching and learning strategies in military officer education. While the report concluded that to a large extent PBL supported the education and development of responsible and independent leaders, until recently those conclusions appear to have been somewhat ignored. More rigorous research is therefore needed to further examine the effects of PBL on student learning outcomes and performance in military education. From a Swedish perspective, Andersson, Lundberg, Jonsson, Tingstrøm and Dahlgren (2013) argue that the Swedish armed forces have used a problem-oriented approach as their educational model since 1998, referring to the Swedish armed forces textbook on pedagogical fundamentals. We have not, however, found empirical studies exploring problem-based learning in a Scandinavian military context.

\section{Framing the Pilot}

The Norwegian Defence University College is the primary provider of professional military education at the master degree level in Norway. A Military Leadership course on the Master's of Military Science programme was used as a pilot case. Teaching methods were changed from more traditional practices to those aligned with the principles of PBL and the flipped classroom, allowing us the opportunity to both tap into new experiences and to compare the pilot with what we had learned from previous courses in military leadership. Flipped classroom 
is a type of blended learning where students are introduced to content at home and practice working through it at school. This is the reverse of the more common practice of introducing new content at school, then assigning homework and projects to be completed by the students independently at home. Theoretically, PBL can be modelled as an ongoing process that normally consists of three phases: problem-presentation and analysis; self-directed learning; and synthesis and reporting (Yew \& Goh, 2016). Figure 1 shows how these phases were structured in the pilot.

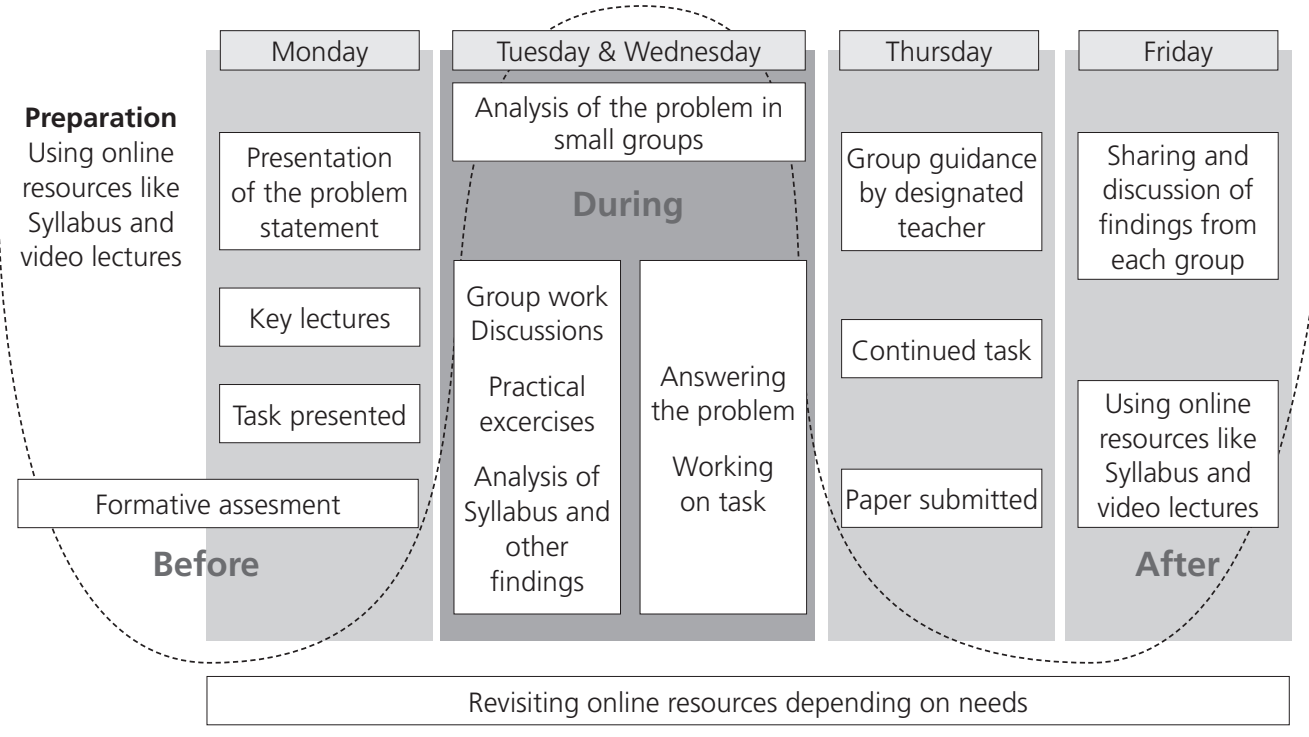

Figure 1: PBL model for the ML course.

\section{Comparing Learning Methodology in the Military Leadership Course - Framing The Pilot}

Predefined learning outcome descriptions developed according to the European Qualification Framework (EQF) and the National Qualification Framework for Lifelong Learning (NKR) are the foundation of all education at NDUG (Norwegian Department of Education, 2011), and form the basis for designing a pedagogical model, developing learning activities and assessments. The LODs for the Military Leadership course contain both knowledge and skill descriptions, meaning that students should acquire a predefined level of knowledge within the subject while developing problem-solving and analytical skills.

The six-week Military Leadership course has traditionally been based on a long-established pedagogical model in line with the definition of Barrows (2002). 
Usually $33 \%$ of the time is used for classroom lectures, while $42 \%$ of the time is set aside for the students to individually read and work with a predefined syllabus. Of the remaining time, $10 \%$ is normally used to facilitate group activities and $15 \%$ is reserved for written and oral summative assessment (Isaksen, 2019). The main difference in the 2019 curriculum compared with that of 2018 was the increased time set aside for group collaboration $(47 \%)$, which was achieved by reducing classroom lectures to $9 \%$ and individual study time to $28 \%$ of the course.

The use of a weekly "problem" was the main pillar of the learning activities in the new pedagogical model. Five problems, one for each of the five first weeks and all based on the predefined learning outcome descriptions, were constructed and attached to a mandatory work requirement. As recommended by Fukuzawa, Boyd and Cahn (2017), short weekly problems were thus chosen instead of prolonged projects, following the framework of Barret and Moore (2011). Each of the six student groups were collectively responsible for developing and submitting a written paper answering the problem, thus serving as a weekly formative assessment tool. The mandatory syllabus was considerably reduced to about 500 pages, leaving the students to identify and add about 300 suitable pages following their own judgment.

Each Monday was set aside for key plenary lectures, summarising the previous week's problem and clarifying the upcoming problem. Every Tuesday and Wednesday, the students decided their learning process for themselves in six designated groups, working on their assigned problem without any teachers present. Thursday was reserved for group-based feedback and guidance before submission of the required paper in the afternoon. An article seminar was also conducted within each group in which the students discussed and criticised different articles relating to the weekly problem. The last day of the week was used to prepare for the upcoming week by reading the syllabus and accessing online video lectures in the Learning Management System (LMS). It was made clear to students from the beginning of the course that the oral exam would be based on one of the five problems tackled during the five weeks. This exercise secures a direct link between the LOD, learning activities and the examination.

\section{Methods and Materials}

We pursued two relatively broad interconnected research questions: did we succeed in constructing (and conducting) a problem-based, student-centric teaching method? And did the change in pedagogy enhance learning outcomes and contribute to any positive outcomes? On one hand, we wanted to learn and understand more about the students' experiences, thoughts, expectations, motives and attitudes to 
generate ideographic knowledge about the pedagogy of problem-based learning and its link to learning outcomes. According to Kraiger, Ford \& Salas (1993), learning outcomes can be categorised as affective-, cognitive- or skill-based. The affective domain is also one of three domains in Bloom's Learning Taxonomy (Bloom, Engelhart, Furst, Hill \& Krathwohl, 1956) and includes how we cope with things emotionally - feelings, for example; values, appreciation, enthusiasm, motivation and attitudes. We also wanted to investigate learning outcomes from the cognitive- and skill-based domains, including measurable and objective variables.

We thus chose to have a pragmatic and explorative approach to our data sources. To collect, systemise and analyse the data gathered from the study, principles of mixed methods were applied, which allowed us to make use of both qualitative and quantitative methodological approaches and measures. This implied integration of those two components through both data collection, analyses and results. These different perspectives on knowledge also allowed a broader and more complete understanding of the subject under scrutiny (Mertens, 2011).

\section{Qualitative Approach}

A qualitative approach allowed the method to materialise as a dynamic process, where the objects of the study were observable during and after the research process (Gentikow, 2005). We employed several types of qualitative approach. Direct and indirect observations made by teachers, supervisors, seminar leaders and staff during the course were collected continuously, discussed and systemised throughout the course. These observations were based on group discussions, informal conversations with the students, colleagues and so forth. From the students' own final course evaluation, we extracted and systematised the free text material. The same approach was conducted with both the College's formal student evaluation and the formal report provided by the course director. Immediately after the oral exam, we gathered all the external examiners to present and discuss their experiences of the examination as input to the analysis.

\section{Quantitative Measures}

The quantitative approach let us use available statistical data (Gentikow, 2005). Several forms of quantitative measures were employed, allowing students to respond anonymously; these measured different aspects of their impressions and experience of, and their attitudes towards, the course, with emphasis on relevance and outcome of a problem-based learning strategy. As we did not employ vali- 
dated scales, reliability procedures were not used (Cortina, 1993). The following questionnaires were employed.

a. A standard feedback evaluation consisting of 16 questions with mixed closed and open-ended items, measuring different aspects of the students' attitudes and experience before, during and after the course. The questionnaire tapped both administrative, pedagogical and professional aspects of the course and is a standardised part of the quality assessment system at the NDUC.

b. A questionnaire to specifically measure the students' attitudes towards PBL and how it influenced their learning outcomes. The questions were asked on two occasions: immediately prior to the beginning of the course, and immediately after the course ended.

c. A questionnaire measuring the extent to which the leadership course offered problem-based teaching in comparison with two other completed courses Scientific Methods (SM) and Politics, Strategy and Military Power (PSM).

d. Additionally, we retrieved and analysed different kinds of statistics available from the Learning Management System (LMS) "Itslearning."

\section{Description of the Course Population - Students at NDUC}

The course comprised 52 students primarily with a military background; four were civilians, five were foreign military exchange students. Of the students, $15 \%$ were women and the rest were men. The average age was 39 years, with the youngest 36 and the oldest 47. Besides being a formally accredited Master's degree programme, the Master's of Military Study programme at the NDUC is, in military terms, a command and staff education functioning as a de facto rite of passage for students set for future higher leadership positions in the military. This implies that, in general, the students have considerable experience from previous leadership positions and are carefully selected based on their potential as future high-level leaders. Representing a highly select group with above-average potential and skills, we expected the students to take responsibility for their own learning, thereby favouring PBL as a learning method. This follows the claim made by Tough (1971) that self-directed learning (SDL) springs from an independent and adult learning context, and Garrison's definition of SDL as an approach where learners are motivated to assume personal responsibility and collaborative control over the cognitive and contextual process (Garrison, 1997). 


\section{Did we Succeed in Providing a Problem-based, Student-centric Teaching Method?}

\section{Students' Perceptions of Problem-Based Teaching}

Initially we selected three questions from the students' standard feedback evaluation (see Table 1 below) to explore the degree to which the students had experienced a PBL learning context during the course. The questions measured occurrence of student-active learning activities, how the pedagogy fit the learning objectives and whether the students participated actively during the course.

\begin{tabular}{|l|l|l|l|l|l|}
\hline $\begin{array}{l}\text { Selected course feedback questions } \\
\text { from the students }\end{array}$ & $\begin{array}{l}\text { Very } \\
\text { high }\end{array}$ & High & Med & Low & $\begin{array}{l}\text { Very } \\
\text { low }\end{array}$ \\
\hline $\begin{array}{l}\text { To what degree do you experience that the } \\
\text { course structure facilitated student-active } \\
\text { learning activities (e.g. group work, reflection } \\
\text { and seminars)? }\end{array}$ & $22 \%$ & $58 \%$ & $10 \%$ & $6 \%$ & $4 \%$ \\
\hline $\begin{array}{l}\text { To what degree do you find the pedagogy to } \\
\text { be in line with the learning objectives in the } \\
\text { course? }\end{array}$ & $20 \%$ & $55 \%$ & $13 \%$ & $7 \%$ & $5 \%$ \\
\hline $\begin{array}{l}\text { To what degree have you participated } \\
\text { actively in the learning environment during } \\
\text { the course? }\end{array}$ & $15 \%$ & $71 \%$ & $8 \%$ & $3 \%$ & $3 \%$ \\
\hline
\end{tabular}

Table 1: Responses from the students on selected standardised feedback questions $(N=32)$.

About $80 \%$ of the respondents experienced a high to very high degree of student-active learning activities, and of having participated actively in the learning environment during the course. In addition, $75 \%$ of the respondents found to a high or very high degree that the pedagogy fit the learning objectives. The results, then, express the fact that the course was constructed to promote a problem-based, student-centric teaching method.

PBL is employed, importantly, with a view to the augmentation of the student's analytical abilities and problem-solving skills (Car et al., 2019; Bishop \& Verleger, 2013; Wood, 2003). The student should also be given opportunities to solve problems in a collaborative setting, to create mental models for learning and to form self-directed learning habits through practice and reflection (Hmelo-Silver, 2004; Norman \& Schmidt, 2004). In addition, critical thinking, problem-solving and analytical skills are a prerequisite for both the understanding and application of mission command and the planning and conduct of military operations (Norwegian Defence University College 2019b). We therefore asked 
the students the following question: "To what degree would you say the teaching method and learning activities in each subject facilitated problem-solving and analysis skills?" The question made it possible to both gather experiences from the ML course and to search for possible differences compared to the other two courses conducted during the first semester (Politics, Strategy and Military Power, and Scientific Methods).

The results offered different interpretations. The majority of the students (close to $70 \%$ of respondents) reported that the ML course itself offered many or very good opportunities to exercise problem-solving and analytical skills, which indicates that PBL took place in line with the expectations of Wood (2003). The students also found that the course offered more opportunities to exercise problem-solving and analytical skills than the other two courses. These differences are interesting: as the other two courses did not base their pedagogy on PBL, we might expect the students to more easily recognise the pedagogical differences.

\section{The Curriculum}

Experiences from PBL indicate that students work actively to acquire knowledge far beyond that of the mandatory curriculum, and collaboration in groups of five to six people improves the breadth and the quality of knowledge they acquire (Bekkhus, Samuelsen, \& Gulbrandsen, 2009). Students also tend to conduct more critical interpretations of material that they select independently (Garrison, 1997). Based on these assumptions, we reduced the mandatory curriculum and allowed the students to collect and apply 300 pages of literature pages themselves, which facilitated increased collaboration and self-directed learning.

During the course, feedback from the librarians indicated that the students drew on the library services significantly more than for the previously completed courses. Asking for further clarification, we learned that the students now asked for, and were assisted with, online search strategies and means of both evaluating the quality of literature and of systemising their findings. The students also used the library as a physical place for one-to-one or small group discussions, addressing both the course literature and academic issues in general with fellow students, teachers and librarians.

\section{The Magic of Group Work?}

The nature of armed forces as collectives points to the necessity of working together in groups. It is also reflected in the Norwegian Armed Forces Governing Principals of Pedagogy (Norwegian Defence University College, 2007), which underlines 
that the learner must be challenged to use their own experiences, conduct critical interpretations and cooperate with others. Student evaluations from several years ago reveal "more time available for group work" to be the most common topic for improvement of the different courses. Johnson, Johnson and Holubec (2008) suggested that group work can be termed "cooperative learning," defined as the instructional use of small groups to promote students working together to maximise their personal and collective learning. If teachers want their group work experience to succeed, the creation of a group atmosphere where these rules can be followed by all group members should be one of their foremost goals.

The six primary groups observed in the Military Leadership course had been functioning from the beginning of the August term, so the premise had, to a certain extent, already been set and the students had three months of prior experience of working together. We observed first-hand that students spent a substantial amount of time in their primary groups, often beyond normal working hours. Other smaller mixed groups were also formed for discussions and the exchange of knowledge. A question from the students' feedback evaluation supported these observations by indicating that the students spent about $50 \%$ more time working in groups this year compared with the three previous years in the Military Leadership course. This must be regarded as a significant increase and indicates a positive learning experience related to group work itself, working to foster intrinsic motivation (Harun et al., 2012). In another open-ended question from the questionnaire, we asked the students to describe which learning activities motivated them to actively participate in the learning situation. The opportunity to work in groups and to manage their own time stood out as the most prominent responses.

Besides substantiating the perceived essence and value of group work, the statements also raised other important aspects of PBL. The quotations revealed dynamics in the students' learning process and reflections on how they actually learned and took responsibility for their own learning. They also coincide with how Garrison (1997) defines SDL, where the learners are motivated to assume personal responsibility and collaborative control over the cognitive and contextual process in constructing and confirming meaningful and worthwhile learning outcomes. The responses also indicated that the study climate in the groups allowed students to propose and discuss a variety of questions targeting the same idea or problem. According to Pan and Rickard (2018) this could support the development of flexible knowledge.

Even though the students embraced group work, responses were not unequivocally positive: during the course, some of the students reported directly to our faculty what they experienced as dysfunctional group processes. Typically, resourceful students took control of the working progress, initiating structure and 
excluding the less resourceful from full participation. Several students mentioned this as a degrading experience. It was emphasised by Johnson et al. (2008) that for a collaboration to work well, equality, mutuality and the creation of meaning that leads to shared understanding must be emphasised. Members of the group must also contribute equally to improve the group's overall understanding of the problem under scrutiny. In their study, Justo, Vazquez-Bosa and Trujillo (2016) argued that uneven participation of group members in group tasks was a common weakness in applications of PBL.

We also observed elements of internal competition at group level. This was to some extent to be expected as both our previous experience and the demographic characteristics of the students suggested a competitive environment. The question of whether or not competition in education can be considered beneficial remains controversial from a research perspective. But the general consensus in the literature, it would seem, is that cooperation is to be preferred to competition since these characteristics are often, but not always, viewed as being opposites (Hattie, 2009). In their study on interventions in dysfunctional learning groups, Hitchcock and Andersen (1997) suggested several improvement strategies, among which were the early establishment of ground rules, directly addressing conflict as it arises, and strategic interventions designed to foster positive group development. How to establish, develop and maintain well-functioning study groups is a subject which should be followed up in later courses and programmes.

\section{Motivation}

According to social learning theory, as the individual must be motivated to learn for actual learning to occur, the motivational and attitudinal component is crucial in education (Bandura, 1977; Bandura \& Wood, 1989). Studies show that engagement and intrinsic motivation play a crucial role in a PBL context, both as antecedents and positive outcomes (Barrow 1997; Wijnen et al. 2018). As intrinsic motivation is based on autonomy, competence and relatedness (Douglass \& Morris, 2014), collaboration, problem-solving and opportunities for critical thinking should be emphasised in the learning process (Murray \& Summerlee, 2007). Following Fukuzawa, Boyd and Cahn (2017), it is fair to argue that intrinsic motivation will increase if the premises for PBL are met and they are linked to perceived learning outcomes. To measure aspects of intrinsic motivation, we inquired about the students' attitudes towards PBL and the concomitant impact on the learning outcomes.

Before the course started, students expressed relatively neutral or positive attitudes towards PBL and about the ways in which the teaching method would influ- 
ence their learning outcomes. After the course, a significant number of students had moved from a neutral or positive to an even more positive position. Two thirds of the respondents were now either positive or very positive. When examining student motivation during problem-based learning implementation, Fukuzawa et al. (2017) found, in support of this change, that by the end of the course the majority of students $(76.7 \%)$ found an increase in their motivation towards PBL. One way to interpret this general change in attitude is to view the responses as a positive reaction to learning experiences received during the course. Hughes et al. (2016) argued that reactions set the stage for more distal outcomes as they signal satisfaction: they serve as indicators of motivation to learn and may lead to other key outcomes in addition.

\section{Does duration and subject matter expertise influence student motivation?}

In their meta-analysis, Strobel and van Barnevald (2009) argued that PBL is significantly more effective than traditional instruction for both the training of competent and skilled practitioners and for the promotion of long-term retention of knowledge and skills acquired during the learning experience. This does not necessarily correlate with the application of PBL over time. Few studies seem concerned with the implications of duration. In our case, this issue is of particular interest since the length of the different courses at the NDUC vary by several weeks.

PBL requires intellectual creativity, which is hard work. By the end of the course, we became aware of a certain "PBL-fatigue" among the students. Random feedback from several students indicated that PBL was becoming more intense and stressful. With its requirement for changes in theoretical approaches and applications of new or different mental models, shifting focus each week to a new subject and problem became increasingly demanding. After four to five weeks, many of the students had obviously reached the point of saturation.

One of the conclusions in the formal student evaluation highlighted that the application of PBL must be considered and adjusted, depending on the length of the course. With regard to motivation, Wijnen et al. (2018) refer to several studies showing that PBL is positively related to motivation when implemented for a short period of time (two to six weeks). The length of the ML course, five weeks, appeared to be a good fit, which may also explain the rise in positive attitudes to PBL among the students. Course duration is an important determinant for future planning and for the use of PBL as a teaching method. Further, the findings oblige us to consider the ways in which working with new and complex problems over time challenges creativity and can be intellectually exhausting; this should 
remind us of the necessity of sustaining our cognitive reserves during military operations, which tend to become drawn out.

\section{Did the Change in Pedagogy Contribute to any Positive Outcomes?}

In the previous section, we found support for the application of a problem-based, student-centric learning method and discovered several avenues of further research. Our second research question explores the extent to which our pilot can be related to positive outcomes. Focusing on the students' academic achievements, here we consider their grades as an index of performance and learning outcomes, as elaborated by Campbell and Cabrera (2014) and Akçayır \& Akçayır (2018).

\section{Academic Achievements in the Individual Oral Exam}

Since the Military Leadership course was the only course during the entire Master's programme to emphasise PBL and flipped classroom principles, we compared the results with the concurrent Strategy and Military Power course to compare any differences between the grades awarded. In PSM the grades were assessed and determined through a written paper. As the learning objectives in the ML course had remained the same for three years, we compared the pilot results with those of the three years before. To investigate possible group differences, we also aggregated and compared the results between the six basic learning groups in the pilot.

Compared with the PSM course and previous results from the ML course, the grades from the pilot appeared remarkably high, showing that above $50 \%$ of the students achieved top grades. A recent empirical study adds further context to these results, showing that in groups of students randomly assigned one of three educational conditions (PBL, lecture-based or self-study groups), students in the PBL group were likely to outperform those assigned the other conditions (Loyens, Jones and Mikkers, 2015). The results are also in line with Akçayır and Akçayır (2018), who suggested that PBL and flipped classroom could lead to learning improvements measured by course grades. It should be noted, however, that the two courses had different assessments (PSM paper, ML oral) which might influence the results.

\section{Observations and Reflections from the Oral Exam}

In pedagogical guidelines developed at Leeds Metropolitan University (Joughin, 2020), it is argued that the oral exam is particularly useful in revealing students' applied problem-solving abilities. Oral assessment can provide insight into students' cognitive processes, providing opportunities for students to critically reflect 
on their work, reflecting the world of practice and improving learning. In this regard, our choice of assessment by oral exam appeared expedient. Four individual examination commissions were established, each consisting of one internal and one external examiner. Six of the examiners had taken part in the pilot and previous courses as educators and examiners.

During the exam, each student was asked to randomly draw one of the five problems tackled during the course. It was theoretically possible for every student to draw the same problem; each problem was, however, represented at least twice in every one of the four examination commissions. While students could use the whiteboard for their presentation, they received no up-front instruction or guidance about how to structure their answers. This was a deliberate decision to counteract the possibility of streamlining and cramming, as we assessed that this approach would contribute to discrimination between the grades and achievements. On the completion of the exam, a meeting with the commissions was arranged to share, discuss and summarise fresh experiences. These experiences were also collected and written in the examiners' reports as a part of the quality assurance system at the NDUC.

Generally, the results follow two paths. First, the examiners declared themselves impressed with the way in which the students tackled the problems they had discussed during the exam, particularly in relation to the demonstration of in-depth knowledge and analytical skills, and in their capacity for critical reflection on the problems. Secondly, the examiners observed that a significant number of students were surprised at their own achievements, and the results obviously surpassed their expectations. Interestingly, more students than usual appeared uncomfortable and showed significant signs of nervousness before and during the examination. The tendency to be more nervous in the face of oral assessments is highlighted by Huxam, Campbell and Westwood (2012). The format we introduced, the lack of a tight "drill" or structure for performance, obviously formed an unfamiliar examination situation. Trusting knowledge both previously gained and newly acquired, however, and applying it in new and unexpected situations, is a hallmark of the military profession. According to Pan and Rickard (2018), having flexible knowledge means that you are able to use what you already know in different ways. As such, the students may have demonstrated an increased level of flexible knowledge without really being aware of it.

\section{Summary and Conclusions}

We have presented above a research study exploring how the principles of PBL affected learning outcomes among Master's students following the Military Lead- 
ership course at the NDUG. By framing the study as a pilot, we used an explorative approach which allowed us to detect new avenues and areas of research rather than simply pursuing and answering hypothesis-based questions. Two basic questions were pursued. Firstly, did we succeed in providing a problem-based, student-centric teaching method? Secondly, did the change in pedagogy enhance learning outcomes for the students?

Supported by the frameworks of Barrows (2002) and Savery (2006), we constructed a pilot in line with theoretical and empirical premises to reach a teaching pedagogy based on the principles of PBL. The use of a weekly "problem" derived from the predefined learning outcome descriptions became the main pillar of the learning activity and set the stage for extensive group work. Through feedback questions, reports and observations. we retrieved and analysed data indicating that the majority of the students benefitted from the course's specific pedagogical apparatus. Group work, highly appreciated and embraced by most of the students, was probably the single largest contributor to their learning outcome. Our findings demonstrated how both well-functioning and less well-functioning groups may relate to important learning experiences and outcomes, whether it be sound and fruitful learning processes or individual examination results. Constructive group work probably contributed to the generation of flexible knowledge, effective problem-solving skills, self-directed learning and effective collaboration skills - several of the positive outcomes of PBL we might expect, according to Barrows (1996). On the other hand, one of the groups we studied in the pilot performed significantly less well than the others, reminding us that the specific constitution of the learning group may be significant, and that some groups may need tighter guidance than others. The establishment and maintenance of effective learning groups appears to be a crucial component in the application of PBL; this represents an important avenue for future research.

Motivation can be regarded as a key resource constituting both a precursor to, and a positive outcome of, PBL. Through our evaluation we discovered both an increase in the students' positive attitudes towards the course and an augmentation in their motivation to learn; these were closely connected to the positive experiences of group work. Nevertheless, it is important to note that a certain number of students also experienced dysfunctional group processes, which adversely affected both learning environment and motivation alike. Course duration may also be a crucial factor in sustaining motivation when applying PBL. We noticed signs of "PBL fatigue" at the end of the course, indicating that the course length of five weeks was probably close to ideal. As previously stated, the course itself influenced students' responses to the teaching methods applied. This 
raises important questions concerning the ways in which PBL may be managed and exploited as a potential teaching method, while keeping in mind that it is not necessarily a "one size fits all" solution at a programme level.

\section{What Can We Learn from this Study?}

Despite the possible advantages offered by the teaching method of PBL in the context of military education, very few empirical studies have been conducted to further our understanding. Our study, thus, advances fresh empirical-based knowledge, widening both the theoretical and empirical field of education and learning, generally, and in the domain of military education more specifically. It supports previous studies and links PBL to positive outcomes while suggesting several further avenues of investigation. Some methodological shortcomings should, however, be mentioned. Being explorative in nature, conclusions regarding cause and effect should be considered tentative. Furthermore, the empirical studies we have used to support our findings are mainly drawn from non-military educational contexts; our findings being based on a military sample conducting military education, this should be taken into consideration when validating their applicability. Nevertheless, we propose PBL as an alternative or supplementary teaching method, especially relevant in military command and staff education.

It should also be noted that PBL enhances learning and skills particularly relevant for the application of both mission command and the planning and conduct of military operations, cornerstones of the military profession. Perhaps our study's main contribution is to serve as an inspiration and a source for further exploration and elaboration regarding the future development of military and civilian executive management education. 
Akçayır, G., \& Akçayır, M. (2018). The flipped classroom: a review of its advantages and challenges. Computers \& Education, 126, 334-345. Doi: 10.1016/j.compedu.2018.07.021

Andersson, S. O., Lundberg, L., Jonsson, A., Tingstrøm, P., \& Dahlgren, M. A. (2013). Interaction, action, and reflection: How medics learn medical care in the Swedish Armed Forces. Military Medicine, 178(8), 861-866. DOI: https://doi.org/10.7205/MILMED-D-13-00048

Bandura, A. (1977). Social learning theory. Englewood Cliffs, NJ: Prentice Hall.

Bandura, A., \& Wood, R. (1989). Effect of perceived controllability and performance standards on self-regulation of complex decision making. Fournal of Personality and Social Psychology, 56(5), 805-814. DOI: http://dx.doi.org/10.1037/0022-3514.56.5.805

Barret, T., \& Moore, S. (2011). An introduction to problem-based learning. In T. Barret, \& S. Moore (Eds.), New approaches to problem-based learning: Revitalizing your practice in higher education (pp. 3-18). London, New York: Routledge.

Barrows, H. S. (1996). Problem-based learning in medicine and beyond: A brief overview. New Directions for Teaching and Learning, 68(3), 3-12. DOI: https://doi.org/10.1002/tl.37219966804

Barrows, H. S. (2002). Is it truly possible to have such a thing as PBL? Distance Education, 23(1), 119-122. DOI: https://doi.org/10.1080/01587910220124026

Bekkhus, E., Samuelsen, F., \& Gulbrandsen, T. (2009). PBL som metode [PBL as Method]. Sykepleien, 90(20), 42-45. DOI: https://doi.ord/10.4220/sykepleiens.2002.0058.

Ben-Shalom, U., \& Shamir, E. (2011). Mission command between theory and practice: The case of the IDF. Defence and Security Analysis, 27(2), 101-115. DOI: https://doi.org/10.1080/14751798.20 11.578715

Bishop, J. L., \& Verleger, M. A. (2013). The flipped classroom: A survey of the research. ASEE National Conference Proceedings, 30(9), 1-18.

Bloom, B. S., Engelhart, M. D., Furst, E. J., Hill, W. H., \& Krathwohl, D. R. (1956). Taxonomy of educational objectives - Handbook 1: The cognitive domain. New York: David McKay Co Inc.

Caforio, G. (2006). Military Officer Education. In G. Caforio (Ed.), Handbook of the sociology of the military (pp. 255-279). Pisa: Springer.

Campell, C. M., \& Cabrera, A. F. (2014). Making the mark: Are grades and deep learning related? Research in Higher Education, 55, 494-507. DOI: https://doi.org/10.1007/s11162-013-9323-6

Car, L. T., Kyaw, B. M., Dunleavy, G., Smart, N. A., Semwal, M., Rotgans, J. I., Low-Beer, N., \& Campbell, J. (2019). Digital problem-based learning in health professions: Systematic review and meta-analysis by the Digital Health Education Collaboration. Fournal of Medical Internet Research, 21(2), e12945. DOI: https://doi.org/10.2196/12945.

Cook, D. L. (1962). The Hawthorne Effect in educational research. The Phi Delta Kappa, 44(3), $116-122$.

Cortina, J M. (1993). What is coefficient alpha? An examination of theory and applications. Fournal of Applied Psychology, 78(1), 98-104. DOI: https://doi.org/10.1037/0021-9010.78.1.98

Dochy, F., Segers, M., Van den Bossche, P., \& Gijbels, D. (2003). Effects of problem-based learning: A meta-analysis. Learning and Instruction, 13(5), 533-568. DOI: https://doi.org/10.1016/S09594752(02)00025-7

Dolmans, D., De Grave, W., Wolfhagen, I., \& Van der Vleuten, C. P. M. (2005). Problem-based learning: Future challenges for educational practice and research. Medical Education, 39(7), 732-741. DOI: https://doi.org/10.1111/j.1365-2929.2005.02205.x

Douglass, C., \& Morris, S. R. (2014). Student perspectives on self-directed learning and assessment. Fournal of the Scholarship of Teaching and Learning, 14(1), 13-25. DOI: https://doi.org/10.14434/ josotl.v14il.3202

Duraid, J., \& Annen, H. (2019). Professional military education: A cross-cultural survey. Berlin: Peter Lang. Fukuzawa, S., Boyd, C. L., \& Cahn, J. (2017). Student motivation in response to problem-based learning. 


\section{References}

Collected Essays on Learning and Teaching, 10, 175-187. DOI: https://doi.org/10.22329/celt. v10i0.4748.

Garrison, S. D. (1997). Self-directed learning: towards a comprehensive model. Adult Education Quarterly, $48(1), 18-33$.

Gentikow, B. (2005). Hvordan utforsker man medieerfaringer? Kvalitativ metode [How to explore media experiences? Qualitative method]. Kritiansand: IJ-Forlaget.

Gleiman, A., \& Zacharakis, J. (2016). Continuing professional education in the military. Nerw Direction for Adult \& Continuing Education, 2016(151), 81-90. DOI: https://doi.org/10.1002/ace.20197

Goode, C. (2019). Best practice principles for professional military education: A literature review. Fournal of Defence Resource Management, 10(2), 5-20.

Harun, N. F., Yusof, K. M., Jamaludin, H., \& Hassan S. A. H. S. (2012). Motivation in problem-based learning implementation. Procedia - Social and Behavioral Sciences, 56, 233-242. DOI: https:// doi.org/10.1016/j.sbspro.2012.09.650

Hattie, J. (2009). Visible learning - A synthesis of over 800 meta-analyses relating to achievement. London: Routledge.

Hitchcock, M. A., \& Andersen, A. S. (1997). Dealing with dysfunctional tutorial groups. Teaching and Learning in Medicine - an International fournal, 9(1), 19-24. DOI: http://dx.doi. org/10.1080/10401339709539808

Hmelo-Silver, C. E. (2004). Problem-based learning: what and how do students learn? Educational Psychology Review, 16(3), 235-266.

Hughes, A. M., Gregory, M. E., Joseph, D. L., Sonesh, S. C., Marlow, S. L., Lacerenza, C. N., \& Salas, E. (2016). Saving lives: A meta-analysis of team training in healthcare. Fournal of Applied Psychology, 101(9), 1266-1304. DOI: https://doi.org/10.1037/apl0000120

Huxam, M., Campbell, F., \& Westwood, J. (2012). Oral versus written assessments: A test of student performance and attitudes. Assessment \& Evaluation in Higher Education, 37(1), 125-136. DOI: https://doi.org/10.1080/02602938.2010.515012

Isaksen, G. (2019). Implementation of a "true" flipped classroom concept at NDUC. Paper presented at I/ITSEC Orlando, Florida, United States.

Johnson, D. W., Johnson, R. T., \& Holubec, E. J. (2008). Cooperation in the classroom (8th edition). Edina, MN: Interaction.

Joughin, G. (2020). A short guide to oral assessment. Retrieved from Leeds Metropolitan University https:// www.qub.ac.uk/directorates/AcademicStudentAffairs/CentreforEducationalDevelopment/ FilestoreDONOTDELETE/Filetoupload,213702,en.pdf

Justo, E., Vazquez-Boza, M., \& Trujillo, A. D. (2016). Implementation of problem-based learning in structural engineering: A case study. International fournal of Engineering Education, 32(6), 25562568.

Kraiger, K., Ford, J. K., \& Salas, E. (1993). Application of cognitive, skill-based, and affective theories of learning outcomes to new methods of training evaluation. Fournal of Applied Psychology, 78(2), 311-328. DOI: http://dx.doi.org/10.1037/0021-9010.78.2.311

Liu, L., Du, X., Zhang, Z., \& Zhou, J. (2009). Effect of problem-based learning in pharmacology education: A meta-analysis. Studies in Educational Evaluation, 60, 43-58. DOI: http://dx.doi. org/10.1016/j.stueduc.2018.11.004

Loyens, S. M. M., Jones, S. H., Mikkers, J., \& van Gog, T. (2015). Problem-based learning as a facilitator of conceptual change. Learning and Instruction, 38, 34-42. DOI: https://doi.org/10.1016/j. learninstruc.2015.03.002

McBride, D. M., \& Snell, R. L. (2017). Applying mission command to overcome challenges. Army sustainment, 57-60. Retrieved from https://www.army.mil/article/179942/applying_mission-command_to_overcome_challenge. 
Mintzberg, H. (2004). Managers, not MBAs: A hard look at the soft practice of managing and management development. San Francisco: Berret-Koehler Publisher Inc.

Murray, J. A., \& Summerlee, A. J. S. (2007). The impact of problem-based learning in an interdisciplinary first-year program on student learning behavior. Canadian Fournal of Higher Education, 37(3), 87-107.

Norman, G. R., \& Schmidt, H. G. (2004). The psychological basis of problem-based learning - A review of the evidence. Academic Medical, 67(9), 557-565.

Norwegian Defence University College (2019a). Utdanningsstrategi 2019-2022 [NDUC Educational Strategy 2019-2022].

Norwegian Defence University College (2019b). Forsvarets fellesoperative doktrine 2019. [Norwegian Armed Forces joint operational doctrine]. Retrieved from http://hdl.handle.net/1 1250/2631948

Norwegian Defence University College (2007c). Forsvarets Pedagogiske Grunnsyn [Norwegian Armed Forces, pedagogical doctrine]. Norwegian Defence University College.

Norwegian Defence University College (2019d). Emnebeskrivelse for LED4101 Militer ledelse (Course description LED4101]. Retrieved at https://utdanning.forsvaret.no/nb/emne/LED4101/658

Norwegian Department of Education (2011). Nasjonalt kvalifikasjonsrammeverk for livslang laring (NKR) (National qualification framework for lifelong learning). Retrieved from https://www.nokut.no/ norsk-utdanning/nasjonalt-kvalifikasjonsrammeverk-for-livslang-laring/

Offerdal, A., \& Jacobsen, J. O. (1993). Auftragstaktik in the Norwegian Armed Forces. Defence and Security Analysis, 9(2), 211-223. DOI: https://doi.org/10.1080/07430179308405581

O'Flaherty, J., \& Phillips, C. (2015). The use of flipped classrooms in higher education: A scoping review. The Internet and Higher Education, 25, 85-95. DOI: https://doi.org/10.1016/j.iheduc.2015.02.002

Oja, J. K. (2011). Using problem-based learning in the clinical setting to improve nursing students' critical thinking: An evidence review. Fournal of Nursing Education, 50(3), 145-151. DOI: https:// doi.org/10.3928/01484834-20101230-10

Palinscar, A. S. (1998). Social constructivist perspectives on teaching and learning. Annual Review of Psychology, 49, 345-375. DOI: https://doi.org/10.1146/annurev.psych.49.1.345

Pan, S. C., \& Rickard, T. C. (2018). Transfer of Test-Enhanced Learning: Meta-Analytic Review and Synthesis. Psychological Bulletin, 144(7), 710-756. DOI: https://doi.org/10.1037/bul0000151

Mertens, D. M. (2011). Publishing mixed methods research. Fournal of Mixed Methods Research, 5(1), 3-6. DOI: https://doi.org/10.1177/1558689810390217

Savery, J. R. (2006). Overview of problem-based learning: Definitions and distinctions. Interdisciplinary Fournal of Problem-based Learning, 1(1), 9-20. DOI: https://doi.org/10.7771/1541-5015.1002

Scoppio, G., \& Covell, L. (2016). Mapping trends in pedagogical approaches and learning technologies: Perspectives from the Canadian, international, and military education contexts. Canadian fournal of Higher Education, 46(2), 127-147.

Shamir, E. (2011). Transforming command: The pursuit of mission command in the U.S., British, and Israeli armies. California: Stanford University Press.

Shin, I-S., \& Kim, J-H. (2013). The effect of problem-based learning in nursing education: A meta-analysis. Advanced Health Science Education Theory Practice, 18(5), 1103-1120. DOI: https://doi. org/10.1007/s10459-012-9436-2

Skaug, R. (2008). Arbeid med Problembasert Laring som Kadettaktiv Laringspedagogikk ved Krigsskolen 2006-2008 (Fagrapport nr 1/08) [Problem-based learning as cadet active learning pedagogic at the Army War Academy 2006-2008 - Technical report 1/2008]. Retrieved from Krigsskolen [Army War Academy] http://hdl.handle.net/11250/160879 


\section{References}

Sookermany, A. M. (2017). Military education reconsidered - A postmodern update. Fournal of Philosophy of Education, 51(1), 310-330. DOI: https://doi.org/10.1111/1467-9752.12224

Strobel, J., \& van Barneveld, A. (2009). When is PBL more effective? A meta-synthesis of meta-analyses comparing PBL to conventional classrooms. Interdisciplinary fournal of Problem-based Learning, 3(1), 44-58. DOI: https://doi.org/10.7771/1541-5015.1046

Torgersen, G. E., \& Herner, S. (2015). Ny pedagogikk for det uforutsettes tidsalder? [A new pedagogy for the unforeseen?). In G. E. Torgersen (Ed.), Pedagogikk for det uforutsette [Pedagogy for the unforeseen] (pp.15-28). Oslo: Cappelen Damm Academic.

Tough, A. (1971). The adult's learning projects. Toronto: Ontario Institutes for Studies in Education.

United States Marine Corps (2019). Commandants planning guidance (38th Commandant of the Marine Corps). Retrieved from https://www.hqmc.marines.mil/Portals/142/Docs/\%2038th\%20 Commandant $\% 27 \mathrm{~s} \% 20$ Planning\%20Guidance_2019.pdf?ver=2019-07-16-200152-700

Hamilton, M. (2019). Prioritizing active learning in the classroom: Reflections for professional military education. In: P E Berg (Ed). Fournal of Military Learning. (pp. 3-18). USA: Army University Press.

Walker, R. W. (2006). The professional development framework. In B. Horn \& R. W. Walker (Eds.), The military leadership handbook (pp. 436-450). Canada, Toronto: Dundurn Press.

Wijnia, L., Loyens, S. M. M., \& Rikers, R. (2019). The problem-based learning process: An overview of different models. In M. Moallem, W. Hung, \& N. Dabbagh (Eds.), The Wiley handbook of problem-based learning. Hoboken, NJ: John Wiley \& Sons. DOI: 10.1002/9781119173243.ch 12

Wijnen, M., Loyens, S M M., Wijna, L., Smeets, G., Kroeze, M., Van der Molen, Ht. (2018). Is problem-based learning associated with students' motivation? A quantitative and qualitative study. Learning Environments Research, 21(2), 173-193. doi. 10.1007/s10984-017-9246-9

Wong, D. K. P., \& Lam, D. (2007). Problem-based learning in social work: A study of student learning outcomes. Research on Social Work Practice, 17(1), 55-65. DOI: https://doi. org/10.1177/1049731506293364

Wood, D. F. (2003). ABC of learning and teaching in medicine: Problem based learning. BMJ, 2003(326), 328-330. DOI: https://doi.org/10.1136/bmj.326.7384.328

\section{Further Reading:}

Barrows, H. S. (1992). The tutorial process. Springfield, Illinois: Southern Illinois University School of Medicine.

Basal, A. (2015). The implementation of a flipped classroom in foreign language teaching. Turkish Online Fournal of Distance Education, 16(4), 28-37. DOI: https://doi.org/10.17718/tojde.72185

Callado-Muñoz, F J., \& Utrero-González, N. (2019). Integration in the European higher education area: the case of military education. Defence Studies, 19(4), 373-391. DOI: https://doi.org/10.1080/ 14702436.2019 .1681897

Cook, D. L. (1962). The Hawthorne Effect in educational research. The Phi Delta Kappa, 44(3), 116-122.

Gilboy, M. B., Heinerichs, S., \& Pazzaglia, G. (2015). Enhancing student engagement using the flipped classroom. Fournal of Nutrition Education and Behavior, 47(1), 109-114. DOI: https://doi. org/10.1016/j.jneb.2014.08.008

Johansen, R. B., Martinussen, M., \& Kvilvang, N. (2015). The influence of military identity on work engagement and burnout in the Norwegian army rapid reaction force. Fournal of Military Studies, 6(1), 1-11. 
O'Flaherty, J., \& Phillips, C. (2015). The use of flipped classrooms in higher education: A scoping review. The Internet and Higher Education, 25, 85-95. DOI: https://doi.org/10.1016/j.iheduc.2015.02.002

Pardo, A., Gašević, D., Jovanovic, J. M., Dawson, S., \& Mirriahi, N. (2018). Exploring Student Interactions with Preparation Activities in a Flipped Classroom Experience. IEEE Transactions on Learning Technologies, 12(3), 333-346. DOI: https://doi.org/10.1109/TLT.2018.2858790

Woods, D. R. (1994). Problem-based learning: Helping your students gain the most from PBL. Waterdown: Ontario.

Yew, E. H. J., \& Goh, K. (2016). Problem-based learning: An overview of its process and impact on learning. Health Professions Education, 2(2), 75-79. DOI: https://doi.org/10.1016/j. hpe.2016.01.004 